\title{
Effects of physical barrier and insect growth regulator on whitefly control and yield of chili pepper (Capsicum annuum L.)
}

\author{
Rosario Algodon Salas ${ }^{1, ~ *, ~ Z e n a i d a ~ C u e v a s ~ G o n z a g a ~}{ }^{1}$, Deng-lin $\mathrm{Wu}^{2}$, Gregory Luther ${ }^{2}$, \\ Paul Arthur Gniffke ${ }^{2}$, Manuel Celiz Palada ${ }^{2}$ \\ ${ }^{1}$ Dept of Horticulture, College of Agriculture \& Food Science, Visayas State University. Baybay City, Leyte, Philippines \\ ${ }^{2}$ AVRDC-The World Vegetable Center, Shanhua, Tainan, Taiwan
}

Email address:

rasalas_horti@yahoo.com (R. A. Salas)

To cite this article:

Rosario A. Salas, Zenaida C. Gonzaga, Deng-lin Wu, Gregory C. Luther, Paul A. Gniffke, Manuel C. Palada. Effects of Physical Barrier and Insect Growth Regulator on Whitefly Control and Yield of Chili Pepper (Capsicum annuum L.). Journal of Food and Nutrition Sciences. Special Issue: Food Processing and Food Quality. Vol. 3, No. 1-2, 2015, pp. 13-19. doi: 10.11648/j.jfns.s.2015030102.13

\begin{abstract}
Whitefly is a serious pest of chili pepper that could cause direct damage on the plant or serve as carrier of viral diseases. A study was conducted at the experimental farm of the Crop and Ecosystem Management Unit of AVRDC-The World Vegetable Center in Tainan, Taiwan, to evaluate the effects of nylon net as physical barrier and pyriproxyfen, an insect growth regulator (IGR), alone or in combination on controlling whitefly and yield of chili pepper. The experiments were laid-out in a randomized complete block design with three replications. The treatments were employed over an open field crop with the crop row covered with nylon net mesh \#32 or \#50 with or without pyriproxyfen applied at recommended rate. Results revealed that nylon mesh \#50 was effective in excluding whiteflies compared to nylon mesh \#32. Pyriproxyfen also reduced the number of whitefly count. However, based on a total of five harvests, yield decreased by $27 \%$ and $42 \%$ under nylon net barrier $\# 50$ and $\# 32$, respectively, compared to open field cultivation. Plants grown under nylon net were significantly taller in length and had higher leaf area index, or leaf and stem dry matter content but lower the fruit dry matter content.
\end{abstract}

Keywords: Integrated Crop Management, Nylon Net, Pyriproxyfen, Whitefly, Chili Pepper

\section{Introduction}

Chili peppers (Capsicum annuum L.) are used as vegetables, spices, medicinal herbs and ornamental plants around the world. These plants belong to the family solanaceae and appear in different forms, shapes, sizes, and colors. Some varieties are pungent and some are not [1]. Its popularity can be traced on its enhancement to food palatability. Chemical analyses revealed that the fruit consists of relatively low content of sodium and calories, but rich in vitamins $\mathrm{A}, \mathrm{C}, \mathrm{E}$ and a good source of folic acid and potassium [2].

Chili peppers are grown either in open fields or in greenhouses and are considered as an important component of the cropping systems in Asia. In terms of area, it ranked first and third as the most important vegetable in Asia and the world, respectively [3]. The production of chili pepper for spice, vegetable, and other uses increases every year. It is estimated that more than 1.5 million hectares, in numerous countries, has been cultivated worldwide, but its variable responses in producing a quality crop in such a wide range of climates and conditions has made it difficult to make generalization on what is the typical method for its sustainable production [4].

Yield of chili pepper in the tropics is often low, usually as a result of poor management practices and rampant disease infection. Survey in Asia by Ali [3] revealed that viruses were the most serious problem in Indonesia, anthracnose in Thailand, powdery mildew in India and phytophthora blight in China. According to farmers, average losses due to disease infection ranged from $7 \%$ in China to $43 \%$ in India from 1998-2002. Average annual losses due to serious disease attacks increased in all countries except China.

Whitefly transmitted geminiviruses of the genus Begomovirus can damage chili crop due to retardation of growth and development, inducing symptoms such as foliar chlorosis and curling, reduced leaf size, inhibited fruit set and 
eventually abnormal fruit development. Significant reductions in yield have been reported from $20 \%$ to $80 \%$ [58]. It was further reported that an early infection may result in total crop failure.

Control of geminiviruses is difficult once plants become infected. The only way to control the disease is by effectively controlling the vector. Farmers relied heavily on insecticides to manage whitefly (Bemisia tabaci). But with continuous application of insecticides, whitefly develops resistance hence no longer effective. Non-chemical methods must be introduced to reduce damage to the environment and to delay the build up of insecticide resistance. The need for alternative measures is even more important in the face of growing consumer demand for safer vegetables. Screens have been found to provide an efficient way of reducing the entry of pests and hence reducing the number of insecticide applications targeting insect pests and vectors.

Another way of controlling whitefly is the application of the insect growth regulator pyriproxyfen. It has been shown to impart low toxicity to mammals, fish and birds and sufficient specificity to make them useful in integrated pest management (IPM) $[9,10]$. It is also non toxic to the bumblebee (Bombus terrestris), which is an insect pollinator [11]. Pyriproxyfen has been shown to be effective in reducing whitefly populations [12]. Moreover, in an earlier study found that in zucchini a reduction in number of whitefly after the application of pyriproxyfen [13]. Pyriproxyfen is known as the juvenile hormone analogue that affects hormonal balance and chitin deposition in juvenile insects and causes deformation and death at molting and pupation [14]. However, so far no study has been conducted on chili pepper using screens and insect growth regulator and hence the current investigation has been rationalized.

The objectives of the study were to investigate the effect of nylon net as physical barrier in controlling whitefly and on the yield of chili pepper; to determine the effectiveness of pyriproxyfen, an insect growth regulator (IGR), in controlling whitefly for chili pepper production; and to compare the effectiveness of physical barrier and insect growth regulator in controlling whitefly and their effects on the yield of chili pepper.

\section{Materials and Methods}

This study was conducted at field \#45 of Crop and Ecosystem Management Unit (CEM) AVRDC- The World Vegetable Center, Shanhua Tainan, Taiwan within the time frame of January 2008 to July 2008. The experiment was laid out in randomized complete block design (RCBD) with four replications. The treatments were: T1- open field crop, T2crop row covered with nylon net mesh \#32, T3- crop row covered with nylon net mesh \#50, T4- open field crop treated with pyriproxyfen at recommended rate (IGR), T5- crop row covered with nylon net mesh \#50 + IGR, and T6- crop row covered with nylon net mesh \#50 + IGR.

Seeds were sown in a plastic tray on December 14, 2007 and placed under plastic house with double door to protect from insects and disease infection during germination and seedling growth. Thirty eight day old seedlings were transplanted in the field on January 21, 2008 at a distance of $0.75 \mathrm{~m} \times 0.5 \mathrm{~m}$ in $30 \mathrm{~cm}$ raised bed with 20 plants per plot. Standard AVRDC cultural management practices for chili peppers were followed for fertilizer application, staking and other crop management practices.

Cabbage plants were established on the surrounding and throughout the trial block to attract whitefly to the experiment. To augment population of whitefly during winter season, whiteflies were collected from greenhouse grown cabbage of the entomology laboratory unit AVRDC using a whitefly collector. About 300 adult whiteflies were released to cabbage plants 1 week after transplanting of chili pepper allowing sufficient time for whitefly multiplication before application of pryriproxyfen (IGR). Subsequent whitefly release was done 1 week after at the same number of whitefly per plot.

A tunnel type row was constructed to support the nylon net barrier. Tunnel width was $3.15 \mathrm{~m}$ and $1.4 \mathrm{~m}$ height. Pyriproxyfen (IGR) was applied 45 days from transplanting to corresponding treatments at the rate of IL IGR: $1000 \mathrm{~L}$ water.

Data gathered include horticultural characteristics, yield and yield components, insect and disease incidence, whitefly count, herbage weight, leaf area index and dry matter partitioning. For whitefly count 5 randomly selected plants per plot in zigzag direction was used. On each sample plants 3 leaves were taken, 1 each from the top, middle and lower canopy and was brought to the laboratory and the number of eggs, nymph and pupa was counted under a microscope. The first and second count was done before application of insect growth regulator then every fortnight thereafter. A total of three counts were done to monitor the effect of insect growth regulator.

Light intensity was monitored by recording light intensity at 9:00am, 12:00noon and at 3:00pm for a period of 2.5 months using a portable light model to established light reduction in treatments with nylon net barrier of different mesh number. Data logger was used in monitoring relative humidity and temperature inside net barrier and in the open field.

\section{Results and Discussion}

\subsection{Horticultural Characteristics}

The net barrier and insect growth regulator did not significantly affect the number of days to flowering and maturity and plant survival at harvest (Table 1). Chili pepper flowered and matured about 57 and 106 days, respectively, from transplanting. Except on chili pepper planted in the open and applied with insect growth regulator with $98 \%$ survival all other treatments had hundred percent survivals. The higher survival was due to favorable condition at the time of planting such as lower temperature and sufficient moisture for growth and development of the plants. 
Plant height was significantly affected by net barrier and insect growth regulator (Table 2). After two weeks from transplanting, plants protected with \#50 mesh net grew taller compared to plants planted net protection. This result was consistent up to 12 weeks from transplanting. Heights of plants under protection with \#32 meshes were comparable to plants provided with \#50 meshes and without protection on the second week. But on the $4^{\text {th }}$ week onwards to the $12^{\text {th }}$ week from transplanting, their heights were significantly smaller than plants with \#50 mesh cover but significantly greater in height to plants without protection. The variability in height between treatments could be due to light intensity differences. As shown in Figure 1, light intensity inside the net barrier was reduced by $22-26 \%$ as compared to the open field. Previously Zewdie reported an increased in sweet pepper plant height under shaded condition [15]. Under continuous low light intensity or when plants are shaded (although light intensity is high) plants become tall and thin [2].

Table 1. Days from transplanting to anthesis and maturity and percent survival of chili pepper as affected by net barrier and insect growth regulator

\begin{tabular}{lccc}
\hline \multirow{2}{*}{ Treatments } & \multicolumn{3}{c}{ Days from transplanting to } \\
\cline { 2 - 4 } & anthesis & maturity & Percent survival (\%) \\
\hline Open & 57.25 & 106 & 100 \\
\# 32 mesh & 57.25 & 105 & 100 \\
\# 50 mesh & 57.25 & 105.5 & 100 \\
Open + IGR & 57.75 & 105.25 & 98.22 \\
\# 32 mesh + IGR & 57.75 & 106 & 100 \\
\# 50 mesh + IGR & 57.25 & 105.75 & 100 \\
Mean & 57.41 & 105.58 & 1.46 \\
CV (\%) & 0.93 & 0.69 & 99.7 \\
\hline
\end{tabular}

Means within a column followed by a common letter are not significantly different at $5 \%$ level of significance based on LSD.

Table 2. Plant height (cm) of chili pepper as affected by net barrier and insect growth regulator

\begin{tabular}{|c|c|c|c|c|c|c|c|c|c|c|c|c|}
\hline \multirow{3}{*}{$\begin{array}{l}\text { Treatments } \\
\text { Open }\end{array}$} & \multicolumn{12}{|c|}{ Plant height $(\mathrm{cm})$} \\
\hline & \multicolumn{2}{|c|}{2 wks } & \multicolumn{2}{|c|}{4 wks } & \multicolumn{2}{|c|}{6 wks } & \multicolumn{2}{|c|}{8 wks } & \multicolumn{2}{|c|}{$10 \mathrm{wks}$} & \multicolumn{2}{|c|}{12 wks } \\
\hline & 6.66 & $\mathrm{c}$ & 7.50 & $\mathrm{c}$ & 15.16 & $\mathrm{~d}$ & 35.20 & $\mathrm{~d}$ & 53.20 & $\mathrm{c}$ & 69.10 & $\mathrm{c}$ \\
\hline \#32 mesh & 7.04 & $\mathrm{bc}$ & 9.66 & $\mathrm{~b}$ & 21.90 & $\mathrm{c}$ & 49.55 & $\mathrm{c}$ & 71.85 & $\mathrm{~b}$ & 84.45 & $\mathrm{ab}$ \\
\hline Open + IGR & 7.06 & $\mathrm{bc}$ & 8.35 & $\mathrm{c}$ & 16.20 & $\mathrm{~d}$ & 35.20 & d & 55.30 & $\mathrm{c}$ & 66.95 & $\mathrm{c}$ \\
\hline \# 32 mesh + IGR & 7.68 & $\mathrm{ab}$ & 10.34 & $\mathrm{ab}$ & 22.12 & bc & 46.70 & $\mathrm{c}$ & 69.70 & $\mathrm{~b}$ & 80.45 & $\mathrm{~b}$ \\
\hline$\# 50$ mesh + IGR & 7.56 & $\mathrm{ab}$ & 11.18 & $\mathrm{a}$ & 24.02 & $a b$ & 52.35 & $a b$ & 75.50 & $a b$ & 89.70 & a \\
\hline Mean & 7.34 & & 9.76 & & 20.69 & & 45.74 & & 67.26 & & 80.05 & \\
\hline $\mathrm{CV}(\%)$ & 7.36 & & 7.62 & & 6.29 & & 7.62 & & 5.61 & & 5.80 & \\
\hline
\end{tabular}

Means within a column followed by a common letter are not significantly different at $5 \%$ level of significance based on LSD.

Table 3. Leaf area index (LAI), herbage (kg) and dry matter (\%) per plant of chili pepper as affected by net barrier and insect growth regulator

\begin{tabular}{|c|c|c|c|c|c|c|c|}
\hline \multirow{2}{*}{ Treatments } & \multirow{2}{*}{ Leaf area index } & \multirow{2}{*}{ Herb- age (kg) } & \multicolumn{4}{|c|}{ Dry matter $(\%)$} & \multirow{2}{*}{ Total dry matter(g) } \\
\hline & & & leaf & stem & root & fruit & \\
\hline Open & $2.42 \mathrm{~cd}$ & $0.64 d$ & $21.99 b$ & $26.62 b$ & 5.55 & $45.84 a$ & 205.10 \\
\hline \# 32 mesh & $3.57 \mathrm{a}$ & $1.01 \mathrm{a}$ & $28.39 \mathrm{a}$ & $40.82 \mathrm{a}$ & 5.53 & $25.26 \mathrm{c}$ & 221.98 \\
\hline Open + IGR & $2.36 \mathrm{~d}$ & $0.72 \mathrm{~cd}$ & $21.90 \mathrm{~b}$ & $28.82 b$ & 5.64 & $43.65 \mathrm{ab}$ & 220.39 \\
\hline \#32 mesh + IGR & $2.91 b c$ & $0.83 b c$ & $25.39 \mathrm{ab}$ & $37.29 \mathrm{a}$ & 5.92 & $31.40 \mathrm{bc}$ & 195.93 \\
\hline \# 50 mesh + IGR & $3.05 \mathrm{ab}$ & $0.74 \mathrm{~cd}$ & $25.17 \mathrm{ab}$ & $37.81 \mathrm{a}$ & 5.68 & $31.33 \mathrm{bc}$ & 214.21 \\
\hline Mean & 2.95 & 0.82 & 24.83 & 35.08 & 5.77 & 34.32 & 214.05 \\
\hline $\mathrm{CV}(\%)$ & 11.79 & 13.57 & 11.91 & 15.63 & 13.84 & 24.76 & 13.76 \\
\hline
\end{tabular}

Means within a column followed by a common letter are not significantly different at $5 \%$ level of significance based on LSD.

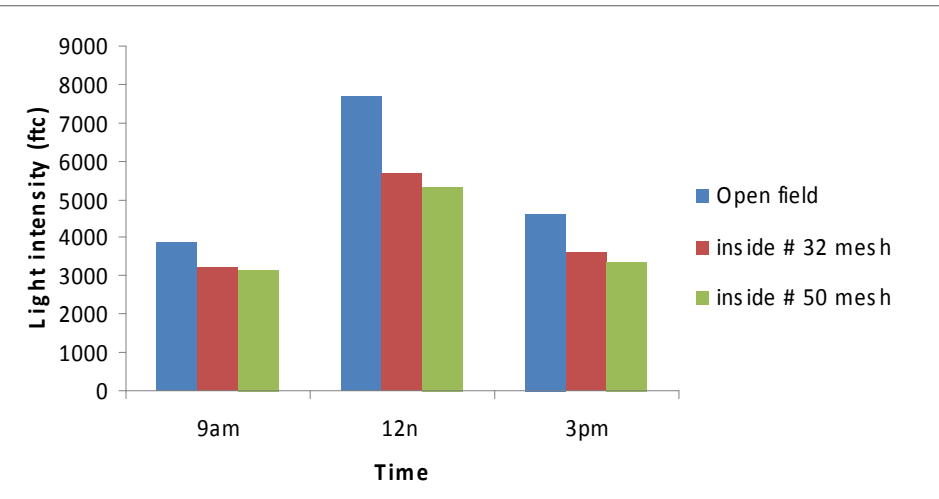

Figure 1. Light intensity (ftc) at 9 am, $12 \mathrm{nn}$ and at 3pm of different growing conditions (open field, inside \#32 mesh and \#50 mesh) 
Table 3 shows the leaf area index and herbage weight and dry matter distribution as affected by net barrier and insect growth regulator. Greater leaf area index was observed in plants covered with nylon net mesh \#32 followed by mesh $\# 50$. Lower leaf area index was produced by uncovered plants. The same trend was observed on the herbage weight of chili pepper. This was due to its taller in height, and thereby producing more leaves compared to plants uncovered. The dry matter distribution of chili pepper at first harvest was significantly affected by the net barrier and insect growth regulator. Plants covered with nylon net produced more leaves and stems and fewer fruits compared to those uncovered plants. Similarly to plants covered with nylon net and applied with insect growth regulator, more leaves and stem were produced than the fruits. The production of more fruit dry matter by the uncovered plants could be due to sufficient amount of light needed for photosynthesis. In covered plants, there was a reduction of light of about 22$26 \%$, for meshes \#32 and 50, respectively. In addition, the higher leaf area index of those plants leads to greater shading of leaves at lower canopy level, hence, limited photosynthesis for leaves, therefore, some leaves acted as sink rather than source. Leaf area index (LAI) gives the ratio of leaf area to the ground area. The crop is usually closed with a LAI of 2.5-4 [16]. With higher LAI utilization of the light by the plant does not increase. It is an important measure of the amount of intercepted radiation by the plant.

The herbage and dry matter distribution of chili pepper at last harvest are presented in Table 4. Results showed significant differences between covered and uncovered plants with and without insect growth regulator. Chili pepper plants protected with nylon net and applied with or without insect growth regulator had higher herbage weight, more leaf and stem dry matter than fruits. The reverse happened to those plants unprotected with or without insect growth regulator. More fruit dry matter and lower in stem and leaf dry matter was produced on uncovered plants with or without insect growth regulator. Except on the uncovered plants applied with insect growth regulator, root dry matter produced was comparable among covered and uncovered plants either with or without application of insect growth regulator. No significant difference was observed on the total dry matter production.

Table 4. Herbage and drymatter at last harvest of chili pepper as affected by net barrier and insect growth regulator

\begin{tabular}{|c|c|c|c|c|c|c|c|c|c|c|c|}
\hline \multirow{3}{*}{$\begin{array}{c}\text { Treatments } \\
\text { Open }\end{array}$} & \multicolumn{11}{|c|}{ Dry matter (\%) } \\
\hline & \multicolumn{2}{|c|}{ Herbage (kg) } & \multicolumn{2}{|c|}{ leaf } & \multicolumn{2}{|c|}{ stem } & \multicolumn{2}{|c|}{ root } & \multicolumn{2}{|c|}{ fruit } & \multirow{2}{*}{$\frac{\text { Total dry matter }(\mathbf{g})}{241.42}$} \\
\hline & 0.68 & $\mathrm{~b}$ & 25.1 & $\mathrm{~b}$ & 37.86 & $\mathrm{~b}$ & 8.09 & $\mathrm{ab}$ & 28.94 & a & \\
\hline \# 32 mesh & 1.08 & a & 30.18 & a & 50.08 & $\mathrm{a}$ & 8.65 & $\mathrm{ab}$ & 11.09 & $\mathrm{~b}$ & 310.24 \\
\hline \# 50 mesh & 1.19 & $\mathrm{a}$ & 30.64 & $\mathrm{a}$ & 48.92 & $\mathrm{a}$ & 8.44 & $a b$ & 12.00 & $\mathrm{~b}$ & 315.30 \\
\hline Open + IGR & 0.66 & $\mathrm{~b}$ & 24.53 & $\mathrm{~b}$ & 36.24 & $\mathrm{~b}$ & 6.82 & $\mathrm{~b}$ & 32.40 & $\mathrm{a}$ & 247.80 \\
\hline \# 32 mesh + IGR & 1.16 & $\mathrm{a}$ & 30.17 & a & 45.31 & $\mathrm{a}$ & 7.20 & $\mathrm{ab}$ & 17.32 & $\mathrm{~b}$ & 320.58 \\
\hline \# 50 mesh + IGR & 1.32 & $\mathrm{a}$ & 28.22 & $a b$ & 47.77 & $\mathrm{a}$ & 7.78 & $a b$ & 16.23 & $\mathrm{~b}$ & 334.65 \\
\hline Mean & 1.01 & & 28.14 & & 44.36 & & 7.83 & & 19.67 & & 295.00 \\
\hline CV $(\%)$ & 22.21 & & 9.93 & & 9.80 & & 13.03 & & 30.58 & & 22.69 \\
\hline
\end{tabular}

Means within a column followed by a common letter are not significantly different at $5 \%$ level of significance based on LSD.

Table 5. Disease and insect rating of chili pepper as affected by net barrier and insect growth regulator insect growth regulator

\begin{tabular}{|c|c|c|c|c|c|c|c|c|c|c|c|}
\hline \multirow{2}{*}{ Treatments } & \multicolumn{6}{|c|}{ Disease rating weeks } & \multicolumn{5}{|c|}{ Insect Rating weeks } \\
\hline & 12 & 16 & 20 & 6 & 8 & 10 & 12 & 14 & 16 & 18 & 20 \\
\hline Open & 1.00 & 1.00 & $1.00 \mathrm{~b}$ & 1.00 & $2.50 \mathrm{~b}$ & $1.50 \mathrm{ab}$ & 2.00 & $1.25 b$ & $2.00 \mathrm{a}$ & 2 & 2 \\
\hline \# 50 mesh & 1.00 & 1.50 & $2.00 \mathrm{a}$ & 1.00 & $1.75 b$ & $1.00 \mathrm{~b}$ & 2.25 & $1.75 \mathrm{ab}$ & $1.25 \mathrm{~b}$ & 2 & 2 \\
\hline Open + IGR & 1.00 & 1.25 & $1.50 \mathrm{ab}$ & 1.00 & $2.00 \mathrm{~b}$ & $1.50 \mathrm{ab}$ & 2.25 & $1.75 \mathrm{ab}$ & $1.75 \mathrm{ab}$ & 2 & 2 \\
\hline \#32 mesh + IGR & 1.00 & 1.25 & $1.50 \mathrm{ab}$ & 1.50 & $4.50 \mathrm{a}$ & $1.75 \mathrm{ab}$ & 2.50 & $1.50 \mathrm{~b}$ & $1.50 \mathrm{ab}$ & 2 & 2 \\
\hline Mean & 1.04 & 1.21 & 1.54 & 1.17 & 26.32 & 2.25 & 1.71 & 1.58 & 1.12 & 2 & 2 \\
\hline CV $(\%)$ & 19.59 & 37.77 & 42.01 & 28.57 & 2.7 & 14.81 & 35.31 & 24.91 & 54.43 & 0 & 0 \\
\hline
\end{tabular}

Means within a column followed by a common letter are not significantly different at $5 \%$ level of significance based on LSD.

Table 5 shows the disease and insect ratings of chili pepper as affected by net barrier and insect growth regulator. Disease rating on the $12^{\text {th }}$ and $16 \mathrm{~h}$ week from transplanting showed no significant differences among treatments. However, on the $20^{\text {th }}$ week, plants grown in net barrier with mesh \#50 exhibited mild southern blight (Sclerotium rolfsii) infection which was significantly different from plants grown in an open field, although not significantly different from the other treatments. The mild infection of southern blight in plants covered with net barrier could be due to higher temperature inside as shown in figure 2. Black et al [17] reported that high temperature favor disease development, although symptom expression may be more severe during dry conditions following wet period. 


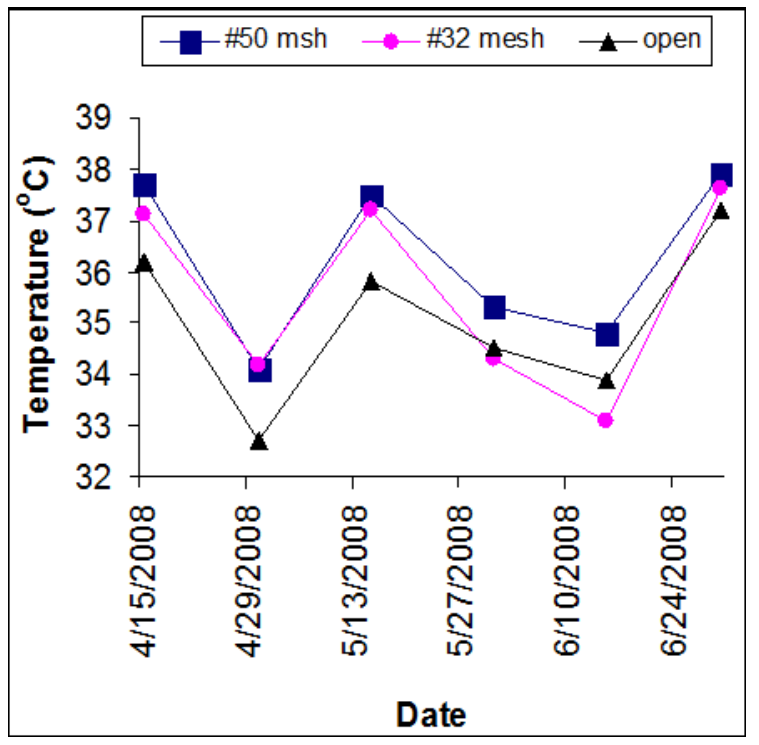

Figure 2. Air temperature in the open field and inside the physical net barrier during the conduct of the second experiment at AVRDC, Taiwan
Six weeks after transplanting, chili plants grown under net barrier with mesh \#32 were mildly infested with aphids and mites though there was no significant difference ever found among treatments. However, 2 weeks after, severe infestation of aphids and mites were observed to plants under the net barrier with mesh \#32 than the rest of the treatments. Net barrier with mesh \#32 was not able to prevent entry of insects onto the chili plants. Additionally, higher internal temperature of the net favored multiplying the insects within short period of time. On the $16^{\text {th }}$ week, significant differences on insect rating were found between plants grown in an open field and those in net barrier with mesh \#50 with the latter exhibiting a less insect infestation than the former. On the $18^{\text {th }}-20^{\text {th }}$ week, there was no significant difference in insect rating of the chili fruits grown in the different treatments as the insects might have entered into the net covered plants during the previous weeks and thus causing no difference as in the open field grown chili plants.

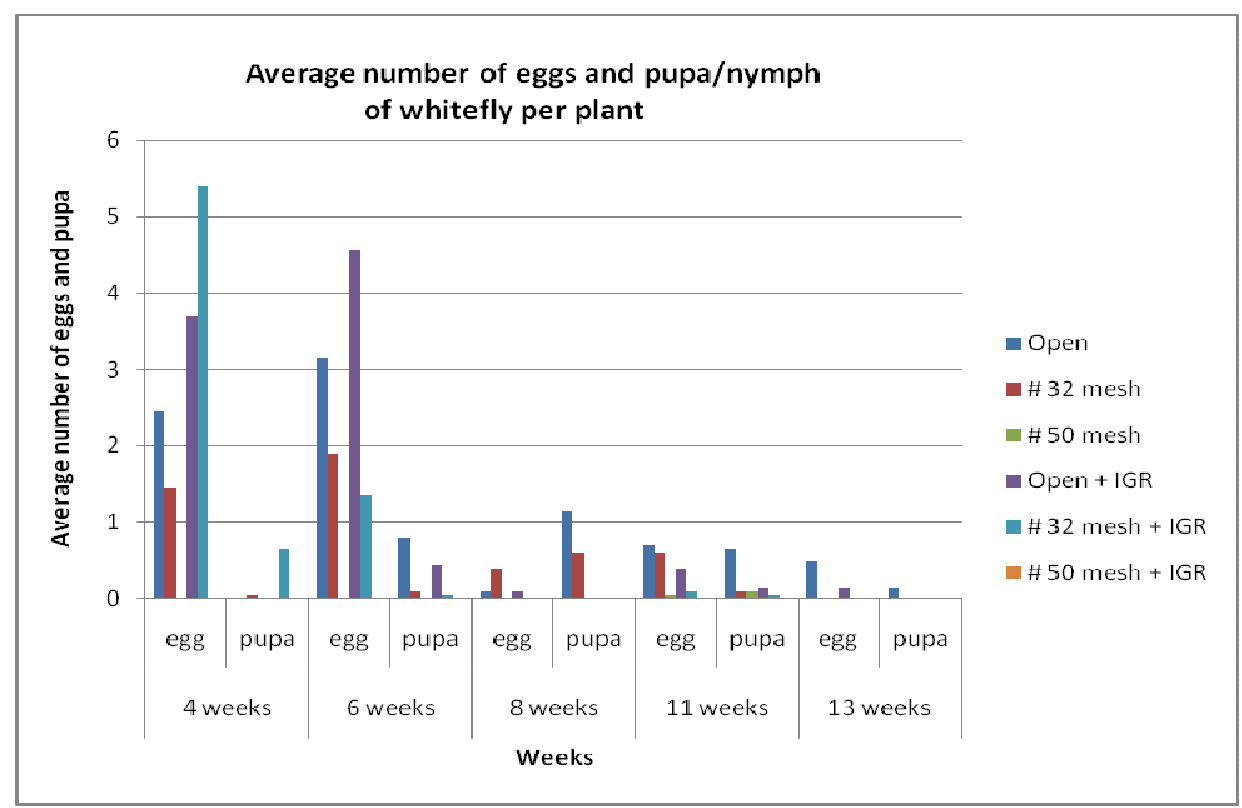

Figure 3. Average number of eggs and pupa/nymph of whitefly on chili pepper leaves as affected by net barrier and insect growth regulator

Table 6. Yield and yield components of chili pepper as affected by net barrier and insect growth regulator

\begin{tabular}{|c|c|c|c|c|c|c|c|c|c|c|c|c|c|c|c|}
\hline \multirow{3}{*}{$\begin{array}{l}\text { Treatments } \\
\text { Open }\end{array}$} & \multicolumn{3}{|c|}{ Fruit size (cm) } & \multicolumn{4}{|c|}{ Marketable fruits/ ha } & \multirow{2}{*}{\multicolumn{2}{|c|}{$\begin{array}{c}\text { Fruit } \\
\text { Weight (g) }\end{array}$}} & \multicolumn{3}{|c|}{$\begin{array}{c}\text { Unmarketable } \\
\text { fruits/ha }\end{array}$} & \multirow{2}{*}{\multicolumn{2}{|c|}{$\begin{array}{c}\text { Total Yield } \\
\text { Fruit \# } \\
\text { F.no(000) } \\
\end{array}$}} & \multirow{3}{*}{$\begin{array}{c}\begin{array}{c}\text { Yield } \\
\text { tons }\end{array} \\
46.12 \mathrm{a}\end{array}$} \\
\hline & \multirow{2}{*}{$\begin{array}{c}\text { Length } \\
14.0\end{array}$} & \multicolumn{2}{|c|}{ Diam. } & \multicolumn{2}{|c|}{$\begin{array}{c}\text { number } \\
\text { F.no (000) }\end{array}$} & \multicolumn{2}{|c|}{ Yield tons } & & & \multicolumn{2}{|c|}{$\begin{array}{l}\text { Number } \\
\text { F.no (000) }\end{array}$} & \multirow{2}{*}{$\begin{array}{c}\begin{array}{c}\text { Yield } \\
\text { tons }\end{array} \\
3.5\end{array}$} & & & \\
\hline & & 2.5 & $\mathrm{a}$ & 2101.0 & $\mathrm{a}$ & 42.6 & a & 20.2 & $a b$ & 285.0 & $a b$ & & 2144.0 & $\mathrm{a}$ & \\
\hline \# 32 mesh & 14.5 & 2.1 & b & 916.0 & $\mathrm{c}$ & 20.3 & $\mathrm{c}$ & 22.4 & $a b$ & 201.0 & $\mathrm{~b}$ & 2.2 & 937.0 & $\mathrm{c}$ & $22.51 \mathrm{c}$ \\
\hline \# 50 mesh & 14.7 & 2.2 & b & 1170.0 & $\mathrm{~b}$ & 21.6 & $\mathrm{bc}$ & 18.7 & d & 234.0 & $a b$ & 2.2 & 1192.0 & $\mathrm{~b}$ & $23.79 b$ \\
\hline Open + IGR & 14.1 & 2.4 & $\mathrm{a}$ & 2170.0 & a & 40.5 & $\mathrm{a}$ & 18.8 & $\mathrm{~b}$ & 255.0 & $a b$ & 2.6 & 2210.0 & $\mathrm{a}$ & $43.12 \mathrm{a}$ \\
\hline \# 32 mesh + IGR & 14.0 & 2.1 & b & 1188.0 & $\mathrm{bc}$ & 24.5 & $\mathrm{bc}$ & 20.7 & $\mathrm{bc}$ & 227.0 & $a b$ & 3.7 & 1213.0 & $\mathrm{bc}$ & $28.22 \mathrm{c}$ \\
\hline \# 50 mesh + IGR & 14.7 & 2.1 & b & 1605.0 & $\mathrm{~b}$ & 31.0 & $\mathrm{bc}$ & 19.7 & $\mathrm{~cd}$ & 319.0 & $a b$ & 3.6 & 1636.0 & b & $34.54 b$ \\
\hline Mean & 14.3 & 2.2 & & 1525.0 & & 18.7 & & 20.0 & & 257.0 & & 3.0 & 1600.0 & & 34.0 \\
\hline CV (\%) & 3.4 & 3.5 & & 17.7 & & 30.9 & & 6.5 & & 25.2 & & 37.0 & 17.7 & & 18.0 \\
\hline
\end{tabular}

Means within a column followed by a common letter are not significantly different at $5 \%$ level of significance based on LSD. 
Figure 3 shows the number of eggs and pupa/nymph of whitefly on chili pepper as affected by net barrier and insect growth regulator. Four weeks after transplanting, no egg of whitefly was ever found on the leaves of the chili plants grown under net barrier with mesh $\# 50$ with or without an insect growth regulator. The same observation was even found up to the $8^{\text {th }}$ week after transplanting for plants grown under the net barrier without an insect regulator and up to the $13^{\text {th }}$ week for plants grown under the net barrier with insect regulator. Some eggs of whitefly were observed on chili plants grown under net barrier with mesh \#32 up to the $11^{\text {th }}$ week. A similar observation was also gathered in plants grown under net barrier with mesh \#32 with insect regulator except on the $8^{\text {th }}$ and $13^{\text {th }}$ week. These results pointed out that the net barrier with mesh $\# 50$ was able to exclude entry of whitefly. On the eight week after transplanting, the addition of IGR to net barrier with mesh \#32 was able to control the population of whitefly as evidenced by zero egg count. The addition of IGR to chili plants grown in the open field gave a reduced egg count. The reduction of whitefly count in this experiment, supported the findings of Qureshi et al [13] in Zucchini. In zucchini, the use of insect growth regulator (IGR) pyriproxyfen reduced the number of whitefly.

On the fourth week after transplanting, only the chili plants under net barrier with or without IGR gave some pupal count. For example, about $4 \%$ of the egg pupated in chili grown under the net barrier with mesh $\# 32$ and about $12 \%$ of the egg pupated in chili grown under the net barrier with mesh \#32 with IGR. Chili grown under the net barrier with mesh \#50 gave no pupal count as there was no egg count observed. The chili plants in the open field had no pupal count as well. Several reasons might have contributed to the no pupal count on plants grown in the open field. First, the open field might have some predators that had consumed the hatching eggs and the eggs might not have pupated at all. Similar trend was observed on the succeeding weeks after transplanting. There seemed to be some slight effect of IGR on the count of pupa as time progressed by. This was clearly shown on the addition of IGR in chili grown in the open and those grown in net barrier with mesh \#32 where the count of pupa was reduced.

The yield of chili pepper as affected by net barrier and insect growth regulator is presented in Table 6. Result showed significant differences on the number and weight of marketable fruits, fruit weight and fruit diameter of chili pepper as affected by net barrier and insect growth regulator. Uncovered plants with or without insect growth regulator produced more number of fruits and consequently gave greater yield compared to covered plants with net mesh \#32 and \#50 and with or without insect growth regulator. Plants covered with net mesh \#50 with or without insect growth regulator significantly produced greater yield compared to plants covered with net mesh \#32 though it is significantly lower than the yield on the uncovered plants with or without protection. The yield increased in the uncovered plants could be due to its bigger fruit diameter and the production of more marketable fruits. Despite the production of higher leaf area, higher leaf and stem dry matter of covered plants with net barrier, yields reduced by $27 \%$ and $42 \%$ when chili was grown under net meshes $\# 50$ and $\# 32$, respectively. The reduction in yield could be due to unbalance vegetative and reproductive growth. The vegetative phase may be dominant over the reproductive phase; in which case, the plant continues to produce more shoots than flowers and fruits, so the balance is tipped on the vegetative phase. When the vegetative phase of plant is dominant over the reproductive, more assimilates are used than stored. In uncovered plants, it may be neither the vegetative nor reproductive phase may be dominant, with the plant producing as much shoots as flowers, so both sides of the balance are practically equal. When the vegetative and reproductive phases are balanced, practically equal amounts of assimilates are used and stored [2]. Additionally, the reduction in yield may be due to reduced light intensity of plants covered with nylon net barrier. This is in agreement with the findings of Zewdie [15] in hot pepper where yield was reduced in shaded plants. Shading during the early vegetative growth stage in tropical regions decreased the number of stomata per $\mathrm{mm}^{2}$ and on the other hand increased more than $40 \%$ the overall dry matter weight.

\section{Conclusions}

Based on the result of the study, the following conclusions were drawn:

1. \#50 mesh nylon net was effective in preventing entry of whitefly;

2. Pyriproxyfen was effective in controlling whitefly; and

3. Yield decreased by $27 \%$ and $42 \%$ when chili was grown under \#50 and \#32 mesh, respectively; and

\section{Recommendations}

For future direction of this research work, the following suggestions are recommended:

1. Pyriproxyfen should be used as a good alternative in controlling whitefly;

2. \#50 mesh may be used if population of viruferous whitefly is a threat; and

3. A follow up study on the physical barrier experiment to include treatments such as removal of nylon net at varying dates from transplanting be done.

\section{Acknowledgments}

The authors would like to thank AVRDC - The World Vegetable Center, Taiwan, Australian Centre for International Agricultural Research, and the Visayas State University (VSU)-Philippines for the financial support to conduct this research project. 


\section{References}

[1] ANDREWS, J. 1999. The Pepper Trail: History and Recipes from Around the World. University of North Texas Press, Denton, Texas. $261 \mathrm{pp}$.

[2] AVRDC. 1990. Vegetable production training manual. Asian Vegetable Research and development center. Shanhua. Tainan. $447 \mathrm{p}$.

[3] ALI, M. 2006. Chili (Capsicum spp.) Food Chain Analysis: Setting Research Priorities in Asia. Shanhua, Taiwan:AVRDC - The World Vegetable Center, Technical Bulletin No. 38, AVRDC Publication 06-678. 253pp.

[4] BOSLAND ,P.W., and VOTAVA, E.J. 2000. Peppers: Vegetable and Spice Capsicums. Crop Production Science in Horticulture 12. CAB International Publishing, Wallingford, England, UK. 204pp.

[5] GREEN, S.K. and KALOO, G. 1994. Leaf curl and yellowing viruses of pepper and and tomato: an overview. Asian Vegetable Research and Development Center. Technical Bulletin No. 21,51pp.

[6] SUMARDIYONO, HARTONO, Y.B., and SULANDARI, S. 2003. Epidemi Penyaki Daun Keriting Duning Cabai. L. Perlind. Tan. Ind., 9(1):1-3

[7] GREEN, S. K., TSAI, W. S., SHIH, S. L. AND BLACK L. L. 2001. Molecular Characterization of Begomoviruses Associated with Leafcurl Diseases of Tomato in Bangladesh, Laos, Malaysia, Myanmar, and Vietnam. Plant Disease, 86(12): 1286

[8] RAHAYA, S.T.S. 2004. Understanding the flight activity for decision making in management of Bemisia tabaci. Master Thesis, Gadja Mada University, Yogyakarta, Indonesia.

[9] ISHAAYA, I. 1990. Benzoyphenyl ureas and other selective insect control agents- mechanism and application. In Pesticides and Alternatives (ed. JE Casida), pp. 365-376. Elsevier Science Publishers, Amsterdam, The Netherlands

[10] DHADIALLA, T.S., CARSON, G.R. and LE, D.P. 1998. New insecticides with ecdysteroidal and juvenile hormone actcity. Annual Review of Entomology, 43:545-569.

[11] DE WAEL, L., DE GREEF, M., VAN LAERE, O. 1995. Toxicity of pyriproxifen and fenoxycarb to bumble bee brood using a new method for testing insect growth regulators. Journal of Apicultural Research 34: 3-8.SCHUSTER, D.J. 1994. Insect control on fresh market tomatoes in west-central Florida. Spring 1993. Arthropod Management Tests 19:150152.

[12] SCHUSTER, D.J. 1994. Insect control on fresh market tomatoes in west-central Florida. Spring 1993. Arthropod Management Tests 19, 150-152.

[13] QURESHI, S.M., MIDMORE, D.J., SYEDA, S.S. and PLAYFORD,C.L.2007. Floating row covers and pyriproxyfen help control silverleaf whitefly Bemisia tabaci (Gennadius) Biotype B (homoptera:Aleyrodidae) in zucchini. Australian Journal of Entomology, 46:313-319

[14] SMITH, K.S. and LISLE, A.T. 1999. Effect of field -weathred residues of pyriproxyfen on the predatory coccinellids Chilocorus circumdatus an Crytolaemus montrouzieri. Australian Journal of Experimental Agriculture 39:995-1000.

[15] ZEWDIE, Y. 1995. Improvement of tropical hot pepper. AVRDC, Shanhua, Tainan, Taiwan. 70p.

[16] SCHOLTE, K. 2001. Methodology in crop experimentation. Department of agronomy Wageningen Agricultural University Haarweg 3336709 RZ Wageningen. 126 p.

[17] BLACK, L.L.,GREEN, S.K., HARTMAN, G.L. and POULUS, J.M. 1991. Pepper Diseases: A Field Guide. Asian Vegetable Research and Development Center. AVRDC Publication N. 91-347, $98 \mathrm{pp}$. 